\title{
Current distribution and coverage of Mexican beech forests Fagus grandifolia subsp. mexicana in Mexico
}

\author{
Ernesto Ch. Rodríguez-Ramírez ${ }^{1}$, Arturo Sánchez-González ${ }^{1, *}$, \\ Gregorio Ángeles-Pérez ${ }^{2}$
}

\begin{abstract}
${ }^{1}$ Laboratorio de Sistemática Vegetal, Centro de Investigaciones Biológicas, Universidad Autónoma del Estado de Hidalgo, Ciudad Universitaria, Carretera Pachuca-Tulancingo Km. 4.5, Mineral de la Reforma, Hidalgo 42184, Mexico

${ }^{2}$ Postgrado Forestal, Colegio de Postgraduados, Montecillo 56230, Texcoco, Estado de México, Mexico
\end{abstract}

\begin{abstract}
Fagus grandifolia subsp. mexicana (Fagaceae) is a taxon endemic to Mexico and is currently considered to be in danger of extinction. It dominates the canopy at the sites where it grows, forming the plant association known as Mexican beech forest. The objectives of this study were to (1) determine the area currently occupied by beech forests in Mexico, based on a literature review; (2) generate maps showing the distribution and area occupied by the less known beech forests in Mexico (which are located in the state of Hidalgo) based on field observations and using geographic information systems; and (3) propose measures that can be taken to protect and manage this plant association. The results show that the beech forests of Mexico currently cover an area of $155.54 \mathrm{ha}$, and several fragments have recently disappeared. The largest patches of beech forest are located at 5 sites in the state of Hidalgo and occupy a total area of 106.79 ha $(73.9 \%)$. Each of the sites is different in size, connectedness, and degree of fragmentation and disturbance. The Mexican beech forests urgently require management and conservation programs, as some of them will otherwise soon disappear due to changes in land use, logging, and climate change. To preserve these forests the following measures are suggested in the short term: increase connectedness between beech forest patches, create core areas, reforest with native species, create seed concentrations, regulate the consumption of beechnuts by humans, and include this plant association in the National System of Natural Protected Areas.
\end{abstract}

KEY WORDS: Mexican beech forest - Fagus grandifolia subsp. mexicana - Forest conservation · Forest management $\cdot$ Mexico

\section{INTRODUCTION}

The genus Fagus (Fagaceae) includes 10 species in the northern hemisphere (Denk 2003, Fang \& Lechowicz 2006). Fossil records of Fagus in Asia and Europe date from the Miocene and the Pliocene (24 to 1.6 million years ago), and in North America from the Eocene (45 million years ago) (Huntley et al. 1989). Continental drift and climate change have drastically decreased the distribution of Fagus (Fonseca et al. 2011, Wilson et al. 2011).

Currently, there are 7 species in eastern Asia: Fagus engleriana, F. hayatae, F. longipetiolata and $F$. lucida in China; F. crenata and F. japonica in Japan; and F. multinervis in Korea (Horikawa 1972). There are also 2 species in Europe and western Asia, F. orientalis and Fagus sylvatica (Rose et al. 2009, Milad et al. 2011); and 1 in North America, F. grandifolia (in 
eastern Canada and the USA). The intraspecific taxon at imminent risk of extinction, F. grandifolia subsp. mexicana (Martínez) A. E. Murray (Valencia \& Flores-Franco 2006), is endemic to Mexico (Miranda \& Sharp 1950, Williams-Linera et al. 2003, SEMARNAT 2010, González-Espinosa et al. 2011).

The first specimens of Fagus collected in Mexico were described as a new species, Fagus mexicana Martínez. The larger fruits and cuneate base of the leaves were the main characteristics that Martínez (1940) used as a criterion to distinguish it from $F$. grandifolia. However, in later taxonomic treatments, the taxon was classified as F. grandifolia var. mexicana (Martínez) Little (Little 1965), and recently it has been classified as Fagus grandifolia subsp. mexicana (Martínez) A. E. Murray (Valencia \& Flores-Franco 2006). Although there is still no conclusive evidence to determine whether it is a species, subspecies or variety, it is clear that this taxon has a disjunct distribution and that its populations in Mexico are at grave risk of extinction (Rowden et al. 2004, Téllez-Valdés et al. 2006, Premoli et al. 2007, Frankham et al. 2012). In this study, it is treated as a subspecies, as proposed in the most recent publications.

The 11 small populations of Fagus grandifolia subsp. mexicana recorded to date are restricted to montane cloud forest in the Sierra Madre Oriental in the states of Hidalgo, Nuevo León, Puebla, San Luis Potosí, Tamaulipas, and Veracruz (Ern 1976, Rowden et al. 2004, Montiel-Oscura 2011). Individuals of this subspecies dominate the canopy at the sites where they grow, forming a plant association known as Mexican beech forest that has specific environmental requirements. They flourish at altitudes of 1400 to $2000 \mathrm{~m}$ above sea level (asl) on high, steep, north-facing slopes with little variation in climate. The annual average temperature ranges between 14.8 and $15.6^{\circ} \mathrm{C}$ and the total annual precipitation exceeds $1741 \mathrm{~mm}$ (Ehnis 1981, Peters 1992, Álvarez-Aquino et al. 2004).

Due to its restricted distribution and narrow range of suitable habitat, Fagus grandifolia subsp. mexicana (Williams-Linera et al. 2003, Fang \& Lechowicz 2006, Téllez-Valdés et al. 2006) has been designated as a taxon in danger of extinction by the Mexican legislature (SEMARNAT 2010) and has been included in the Red List of Mexican cloud forest trees (González-Espinosa et al. 2011). Several other species characteristic of the beech forest canopy and sub-canopy are also included in Mexican risk categories (SEMARNAT 2010, González-Espinosa et al. 2011) and/or international registers of threatened species (CITES 2010), e.g. Clethra mexicana, Cyathea fulva, Dicksonia sellowiana, Magnolia schiede- ana, Pinus patula, Podocarpus matudae, and Quercus laurina (Ehnis 1981, Pérez-Rodríguez 1999, Williams-Linera et al. 2003).

Several authors consider that the information about the distribution, coverage, and conservation status of the beech forests in Mexico is still incomplete (Martínez 1940, Miranda \& Sharp 1950, Fox \& Sharp 1954, Alcántara \& Luna-Vega 2001, Williams-Linera et al. 2003). In this sense, the working hypothesis of the present study is that the current area and distribution of beech forest in Mexico is much more extensive than has been postulated to date, since there are large unexplored, well-conserved areas within the montane cloud forest where climate conditions are ideal for this plant association.

\section{MATERIALS AND METHODS}

\section{Compilation of bibliographic data}

A literature search was conducted to discover which parts of Mexico are known to contain beech forests and which of these already have adequate information about the area and current status of these forests. According to several of the sources consulted (Alcántara \& Luna-Vega 2001, Williams-Linera et al. 2003, Godínez-Ibarra et al. 2007), the state of Hidalgo contains Mexico's largest Fagus grandifolia subsp. mexicana forests, but the least amount of information is available about them (except for the forest located in La Mojonera in the municipality of Zacualtipán de Ángeles). We therefore chose the state of Hidalgo as a suitable place to gather local data to complement existing national data on the distribution, area, and current status of beech forests.

\section{Study area}

The study was carried out in the montane cloud forest in the Sierra Madre Oriental mountain range in the eastern part of the state of Hidalgo, Mexico $\left(20^{\circ} 19^{\prime}\right.$ to $20^{\circ} 38^{\prime} \mathrm{N}, 98^{\circ} 14^{\prime}$ to $\left.98^{\circ} 36^{\prime} \mathrm{W}\right)$. The study sites (El Gosco, El Reparo, La Mojonera, Medio Monte, and Tutotepec) are isolated patches imbedded in the cloud forest, and the canopy is dominated by Fagus grandifolia subsp. mexicana (Fig. 1). This plant association is found between 1557 and $1997 \mathrm{~m}$ asl.

The climate where the Mexican beech forests grow is $\mathrm{Cf}_{\text {; }}$ it is humid temperate with year-round rains, characteristic of a mountain orobiome (García 1988, Peters 1995), it has a relatively high humidity of 60 to 
$85 \%$ (Tinoco-Rueda et al. 2009), is frequently foggy, and has an annual average temperature of $12.7^{\circ} \mathrm{C}$ and a minimum low of $-10^{\circ} \mathrm{C}$. The predominant soil is humic and vitric andosol (FAO-UNESCO 1988). The soil texture is sandy clay loam, with volcanic glass in some places, and the pH ranges from 4 to 6 (Peters 1995).

\section{Fieldwork and herbarium review}

Fieldwork was carried out in various regions of the state of Hidalgo between 2010 and 2011. The beech forests were located based on: (1) specimens from the herbariums MEXU (Instituto de Biología de la Universidad Nacional Autónoma de México), HGOM (Centro de Investigaciones Biológicas de la Universidad Autónoma del Estado de Hidalgo), and XAL (Instituto de Ecología A.C.); (2) data from previous studies (Miranda \& Sharp 1950, Williams-Linera et al. 2003, Rodríguez-Ramírez \& Moreno 2010); (3) investigation of towns or localities near the beech forests where environmental conditions were suitable for this plant association (Williams-Linera et al. 2003, Rodríguez-Ramírez \& Moreno 2010); and (4) showing photographs of Fagus grandifolia subsp. mexicana trees and botanical specimens (branches with leaves and inflorescences) to residents of villages near the montane cloud forests, asking them if they were familiar with the species.

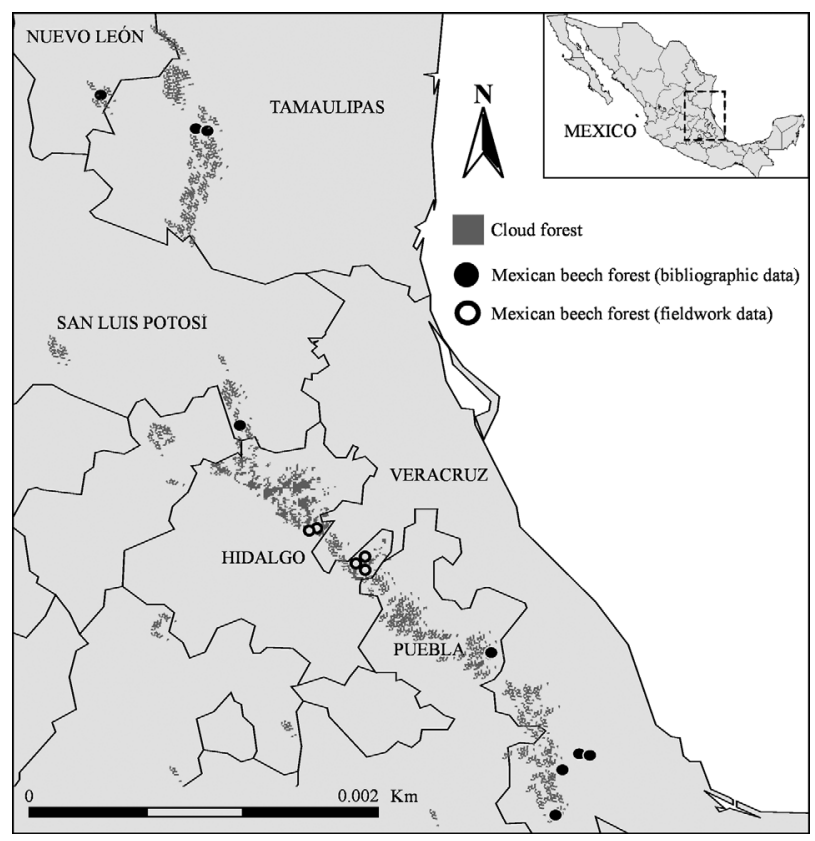

Fig. 1. Fagus grandifolia subsp. mexicana. Current distribution of Mexican beech forest in Mexico

\section{Patch size estimation}

The size of each forest patch was measured by walking around its perimeter and recording georeferences (UTM coordinates, using a GPS map, GARMIN ${ }^{\circledR}$, 6OCSx). Since the Mexican beech forests grow in rugged terrain, digital elevation models that take into account the depth of slopes and/or ravines were used to collect more reliable data on the area, coverage, distribution, and degree of fragmentation of each forest (Maxwell 1982). Calculations were carried out with the ArcView ${ }^{\circledR}$ V.3.3 program (ESRI 2002). In addition, polygons were drawn of each forest patch using USGS Landsat 2012 images (http://glovis.usgs.gov/) with a $3 \mathrm{~m}$ level of resolution. The 'Shape to KML' extension of the ArcView program was used to draw the outlines of each patch on Google Earth ${ }^{\circledR}$ V.6 (2011 and 2012) color photos.

\section{Selecting areas for conservation in each forest patch}

In order to draw the core areas, the polygons of each forest patch were used, with buffers of different diameters, using the 'Patch analyst 3.1' extension of the ArcView ${ }^{\circledR}$ V.3.3 program with the 'create core areas' option (Elkie et al. 1999, ESRI 2002, Girvetz \& Greco 2007). The core area of each forest was arbitrarily defined as a 'minimally disturbed' site or micro-environment located away from gaps or roads (to avoid the edge effect) and with high moisture uptake (due to the presence of water bodies: rivers, streams, or springs). We believe that the selected core areas are those with the best environmental conditions for conservation and management of this plant association. In addition, the continuity of each patch was examined using USGS Landsat 2012 images (http://glovis.usgs.gov/), as an essential factor for increasing the probability of preserving environmental processes at each site (Forman 1995).

\section{Measurement of fragmentation and connectedness}

The 'PatchGrid' extension for ArcView ${ }^{\circledR}$ V.3.3 (Riitters et al. 1995, ESRI 2002), with the 'spatial statistics by regions' option (Elkie et al. 1999), was used to estimate the degree of fragmentation and connectedness of each beech forest. The size metrics, edge metrics, shape metrics, core area metrics, and interspersion metrics statistics were used. In order to find the number of forest patches at each site, the number 
of patches (NumP) and mean patch size (MPS) statistics were calculated. The perimeter of each patch was estimated using the total edge (TE) and edge density (ED) indexes, and the shape of each patch was determined using the mean shape index (MSI) and area-weighted mean shape index (AWMSI).

Spatial configuration, adjacency, and degree of interspersion between closely located forest patches were obtained using the interspersion and juxtaposition index (IJI), which indicates how evenly forest patches are distributed. The lower (closer to zero) the value of the index, the more randomly the patches are distributed in the landscape, while higher values (closer to 100) mean that patches are more evenly dispersed (Forman \& Godron 1981, Elkie et al. 1999). The distance between nearest patches was estimated using the mean nearest neighbor distance index (MNN; Riitters et al. 1995, Gelet et al. 2010).

\section{RESULTS}

\section{Size and current distribution of Mexican beech forest}

Based on bibliographic information and field exploration in the state of Hidalgo, 14 areas were found in Mexico where these forests originally existed. However, the Mexican beech forest plant association currently grows in only 11 of these areas. At the remaining 3 (Chucuyul-Chiconquiaco, HueytemalcoXiutetelco, and Xilitla), it has disappeared or only a few individuals are left, as a result of human activities (changes in land use and deforestation). No references were found regarding the size of the beech forest at Ojo de Agua de los Indios (Table 1).

The data obtained indicate that there are currently beech forests in the states of Hidalgo, Nuevo León, Tamaulipas, and Veracruz, with a total area of $144.54 \mathrm{ha}$, and that they have virtually disappeared from the states of Puebla and San Luis Potosí.

\section{Main characteristics of Mexican beech forest in Hidalgo}

Information provided by the residents of nearby villages has been very useful for locating, describing, and formulating management and conservation proposals for these forests. The results indicate that beech forests are present in 5 areas and 3 municipalities in the state of Hidalgo, and that they are all different in terms of size, connectedness, degree of frag- mentation, and disturbance (Fig. 2). The 5 forests (listed below) are known as 'Haya' (beech) in San Bartolo Tutotepec and Zacualtipán de Ángeles and as 'Tototlcal' in Tenango de Doria.

(1) La Mojonera (El Hayal), Zacualtipán de Ángeles municipality (Tables $1 \& 2$ ). This is one of the largest, best studied, and least disturbed beech forests in Mexico. Peters (1992) and Williams-Linera et al. (2003) state that its area is $45 \mathrm{ha}$, but in the present study it was estimated to be 42.5 ha (Table 1). It lies between 1780 and $1950 \mathrm{~m}$ asl, with a slope exceeding $20^{\circ}$. This site has Fagus grandifolia subsp. mexicana seedlings, but they are not as numerous as in other beech forests in Hidalgo. The forest is located in a temperate orobiome (Peters 1992) typical of montane environments, with a summer rainy season and temperatures ranging between 11 and $18^{\circ} \mathrm{C}$.

(2) El Reparo site, Zacualtipán de Ángeles municipality (Tables $1 \& 2$ ). This beech forest is the most continuous and has the lowest degree of disturbance. It is located $2.4 \mathrm{~km}$ from the La Mojonera forest between 1966 and $1987 \mathrm{~m}$ asl, with an area of 11.55 ha and pronounced slopes $\left(>40^{\circ}\right)$. This small forest is very important to the residents of the village of El Reparo because they use it for their water supply, and are therefore trying to preserve it. The temperature ranges between 11 and $17^{\circ} \mathrm{C}$, and the orobiome is similar to that at La Mojonera, except that in the sheltered areas there are a large number of tree ferns (Cyathea fulva and Dicksonia sellowiana) and several bodies of water (streams and rivers). Many Fagus grandifolia subsp. mexicana juveniles were observed, and evidence of anthropogenic disturbance was only present at the edge of the forest near the road.

(3) El Gosco site, Tenango de Doria municipality (Tables 1 \& 2). This is the smallest beech forest in Hidalgo (4.5 ha) and the one with the most evident disturbance from illegal logging. The orobiome is similar to that of the La Mojonera forest. This forest is located between 1557 and $1864 \mathrm{~m}$ asl in rugged terrain (slopes $>40^{\circ}$ ), with temperatures ranging from 10 to $17^{\circ} \mathrm{C}$. The forest is severely fragmented, but some patches grow in steep ravines, out of human reach, so they are barely disturbed. The finding of this forest adds a record to the known distribution of Fagus grandifolia subsp. mexicana in the state of Hidalgo.

(4) Medio Monte (Las Hayas) site, San Bartolo Tutotepec municipality (Tables $1 \& 2$ ). This is one of the largest ( $34.25 \mathrm{ha})$ and least disturbed beech forests. It has a similar orobiome to that of El Reparo and Tutotepec, which are the 3 forest sites with the least or no evidence of human disturbance. This 
Table 1. Fagus grandifolia subsp. mexicana. Current distribution and area of Mexican beech forests. 1: good; 2: stable; 3: under threat of extinction; 4: extinct

\begin{tabular}{|c|c|c|c|c|c|c|c|}
\hline State & Locality/municipality & $\begin{array}{l}\text { Area } \\
\text { (ha) }\end{array}$ & $\begin{array}{l}\text { Elevation } \\
\quad(\mathrm{m})\end{array}$ & Latitude & Longitude & Status & Source \\
\hline \multirow[t]{5}{*}{ Hidalgo } & $\begin{array}{l}\text { Medio Monte/San Bartolo } \\
\text { Tutotepec }\end{array}$ & 34.25 & $1800-1944$ & $20^{\circ} 24^{\prime} 50^{\prime \prime} \mathrm{N}$ & $98^{\circ} 14^{\prime} 24^{\prime \prime} \mathrm{W}$ & 1 & Present study \\
\hline & $\begin{array}{l}\text { Tutotepec/San Bartolo } \\
\text { Tutotepec }\end{array}$ & 13.99 & $1909-1943$ & $20^{\circ} 24^{\prime} 39.14^{\prime \prime} \mathrm{N}$ & $98^{\circ} 16^{\prime} 52.2^{\prime \prime} \mathrm{W}$ & 1 & Present study \\
\hline & El Gosco/Tenango de Doria & 4.5 & $1557-1864$ & $20^{\circ} 19^{\prime} 37.8^{\prime \prime} \mathrm{N}$ & $98^{\circ} 14^{\prime} 57.1^{\prime \prime} \mathrm{W}$ & 3 & Present study \\
\hline & $\begin{array}{l}\text { La Mojonera/Zacualtipán } \\
\text { de Ángeles }\end{array}$ & 42.5 & $1780-1950$ & $20^{\circ} 38^{\prime} 0.33^{\prime \prime} \mathrm{N}$ & $98^{\circ} 36^{\prime} 51.8^{\prime \prime} \mathrm{W}$ & 1 & Present study \\
\hline & $\begin{array}{l}\text { El Reparo/Zacualtipán } \\
\text { de Ângeles }\end{array}$ & 11.55 & $1966-1987$ & $20^{\circ} 38^{\prime} 05.8^{\prime \prime} \mathrm{N}$ & $98^{\circ} 35^{\prime} 13.4^{\prime \prime} \mathrm{W}$ & 1 & Present study \\
\hline Nuevo León & Agua Fria/Aramberri & 26 & 1830 & $24^{\circ} 02^{\prime} \mathrm{N}$ & $99^{\circ} 42^{\prime} \mathrm{W}$ & 1 & Montiel-Oscura (2011) \\
\hline Puebla & $\begin{array}{l}\text { No reference/ } \\
\text { Hueytemalco-Xiutetelco }\end{array}$ & - & 1450 & $19^{\circ} 53^{\prime} 32.1^{\prime \prime} \mathrm{N}$ & $97^{\circ} 19^{\prime} 49.1^{\prime \prime} \mathrm{W}$ & 4 & $\begin{array}{l}\text { Williams-Linera et al. } \\
(2000,2003)\end{array}$ \\
\hline $\begin{array}{l}\text { San Luis } \\
\text { Potosí }\end{array}$ & Xilitla/Xilitla & - & - & $21^{\circ} 22^{\prime} \mathrm{N}$ & $99^{\circ} 93^{\prime} \mathrm{W}$ & 4 & $\begin{array}{l}\text { Williams-Linera et al. } \\
(2003)\end{array}$ \\
\hline \multirow[t]{2}{*}{ Tamaulipas } & $\begin{array}{l}\text { Casa de Piedra, El Cielo } \\
\text { Biosphere Reserve/ } \\
\text { Gómez Farias }\end{array}$ & 3 & 1500 & $23^{\circ} 03^{\prime} 57.8^{\prime \prime} \mathrm{N}$ & $99^{\circ} 12^{\prime} 3.8^{\prime \prime} \mathrm{W}$ & 3 & $\begin{array}{l}\text { Williams-Linera et al. } \\
(2003)\end{array}$ \\
\hline & $\begin{array}{l}\text { Ojo de Agua de los } \\
\text { Indios, El Cielo Biosphere } \\
\text { Reserve/Ocampo }\end{array}$ & - & 1500 & $23^{\circ} 03^{\prime} \mathrm{N}$ & $99^{\circ} 12^{\prime} \mathrm{W}$ & 3 & $\begin{array}{l}\text { Williams-Linera et al. } \\
\text { (2003) }\end{array}$ \\
\hline \multirow[t]{4}{*}{ Veracruz } & $\begin{array}{l}\text { Mesa de la Yerba/ } \\
\text { Acajete }\end{array}$ & 4.05 & 1900 & $19^{\circ} 33^{\prime} 37.2^{\prime \prime} \mathrm{N}$ & $97^{\circ} 01^{\prime} 9.8^{\prime \prime} \mathrm{W}$ & 3 & Williams-Linera et al. \\
\hline & $\begin{array}{l}\text { Acatlán Volcano crater/ } \\
\text { Acatlán }\end{array}$ & 4.13 & 1840 & $19^{\circ} 40^{\prime} 46.9^{\prime \prime} \mathrm{N}$ & $96^{\circ} 51^{\prime} 9.8^{\prime \prime} \mathrm{W}$ & 2 & $\begin{array}{l}\text { Williams-Linera et al. } \\
(2000,2003)\end{array}$ \\
\hline & $\begin{array}{l}\text { Acatlán Volcano top/ } \\
\text { Acatlán }\end{array}$ & 0.57 & 1900 & $19^{\circ} 40^{\prime} 57.5^{\prime \prime} \mathrm{N}$ & $96^{\circ} 51^{\prime} 15.3^{\prime \prime} \mathrm{W}$ & 2 & $\begin{array}{l}\text { Williams-Linera et al. } \\
(2000,2003)\end{array}$ \\
\hline & Chucuyul/Chiconquiaco & - & 1750 & $19^{\circ} 46^{\prime} \mathrm{N}$ & $96^{\circ} 48^{\prime} \mathrm{W}$ & 4 & $\begin{array}{l}\text { Williams-Linera et al. } \\
(2003)\end{array}$ \\
\hline Total area & & 144.54 & & & & & \\
\hline
\end{tabular}
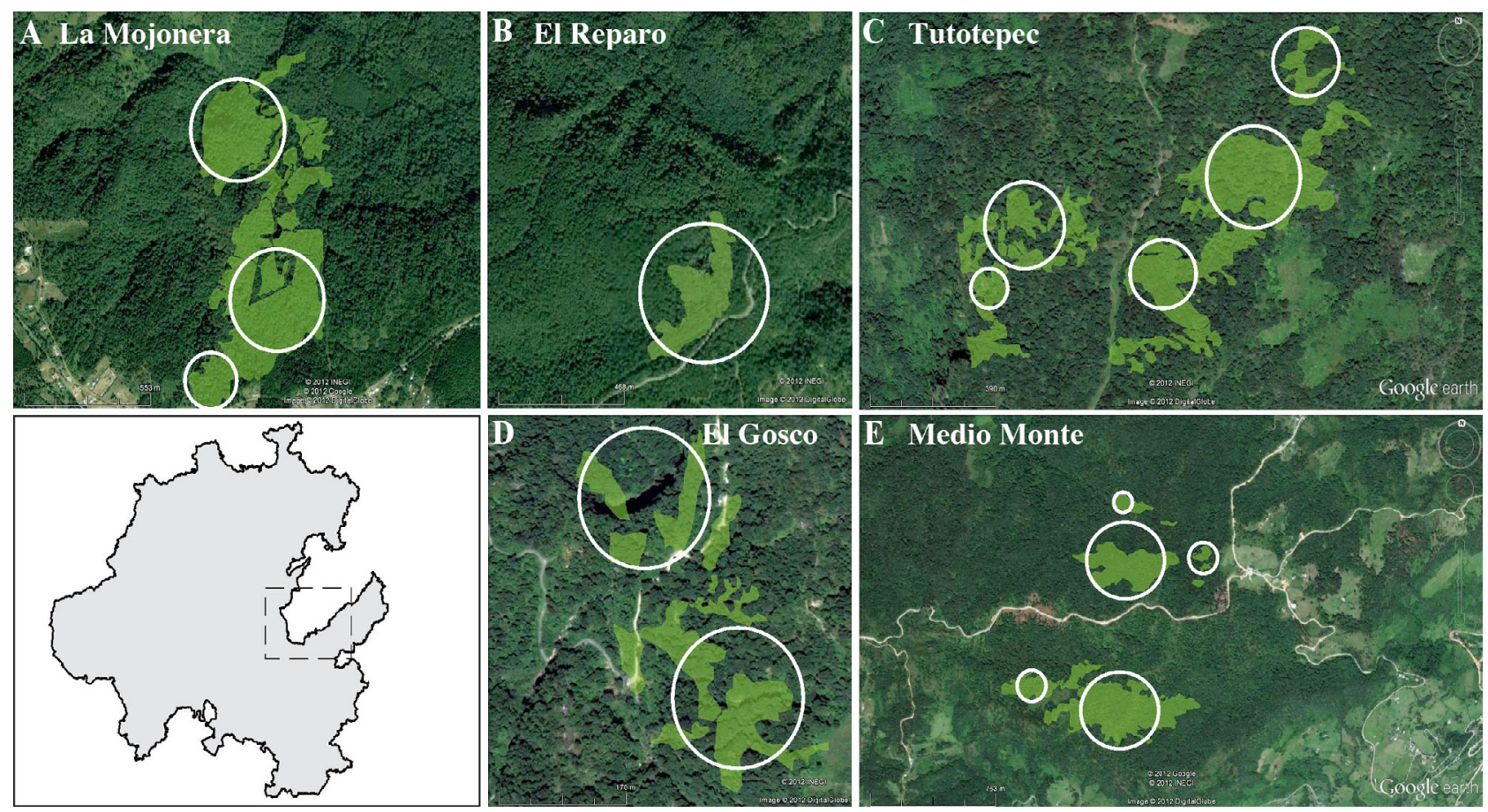

Fig. 2. Size and distribution of Mexican beech Fagus grandifolia subsp. mexicana forests in Hidalgo State (light green areas in A to E). The circles represent the proposed core areas. Inset: the sampling area in Hidalgo 
Table 2. Fagus grandifolia subsp. mexicana. Size, characteristics, rates of change, and proposed core areas of Mexican beech forests in the state of Hidalgo, Mexico. Numbers listed under 'Proposed core areas' represent circles in respective areas shown in Fig. 2. NumP: no. of patches; MPS: mean patch size; ED: edge density; AWMSI: area-weighted mean shape index; MNN: mean nearest neighbor distance; IJI: interspersion juxtaposition index; (-): data not estimated

\begin{tabular}{|c|c|c|c|c|c|}
\hline & La Mojonera & El Reparo & $\begin{array}{l}\text { - Locality } \\
\text { Tutotepec }\end{array}$ & El Gosco & Medio Monte \\
\hline \multicolumn{6}{|c|}{ Slope (degrees) } \\
\hline Min. & 1.8 & 3 & 0.45 & 16.1 & 0.45 \\
\hline Max. & 37.8 & 37.0 & 24.9 & 43.8 & 21.5 \\
\hline \multicolumn{6}{|l|}{ Size metrics } \\
\hline NumP & 4 & 1 & 7 & 7 & 8 \\
\hline MPS (ha) & 10.78 & 11.46 & 1.99 & 0.65 & 4.10 \\
\hline $\begin{array}{l}\text { Edge metri } \\
\operatorname{ED~}(\mathrm{m})\end{array}$ & 350.86 & 352.49 & 274.42 & 1073.08 & 922.25 \\
\hline \multicolumn{6}{|c|}{ Shape metrics } \\
\hline AWMSI (m) & 4.12 & 3.32 & 4.56 & 1.10 & 4.50 \\
\hline MNN (m) & 6.46 & 0 & 8.69 & 12.18 & 38.53 \\
\hline \multicolumn{6}{|c|}{ Interspersion metrics } \\
\hline IJI $(\%)$ & 98.5 & 97.2 & 80.3 & 30.4 & 99.1 \\
\hline \multicolumn{6}{|c|}{ Proposed core areas (radius; m) } \\
\hline 1 & 108.55 & 310.8 & 114.71 & 124.27 & 227.29 \\
\hline 2 & 216.36 & - & 86.62 & 111.19 & 218.41 \\
\hline 3 & 216.36 & - & 86.62 & - & 83.44 \\
\hline 4 & - & - & 68.79 & - & 83.44 \\
\hline 5 & - & - & 36.94 & - & 51.53 \\
\hline
\end{tabular}

through the creation of core areas. We suggest that 5 core areas be established for the Medio Monte site and the Tutotepec site based on the area, state of conservation, and existence of less perturbed sites in these 2 forests (Table 2). For the La Mojonera site, 3 core areas are proposed based on its area and state of conservation. For the El Reparo site, a single core area is proposed, as this forest covers 11.5 ha, is continuous, and shows little evidence of disturbance (Fig. 2). Two core areas are suggested for the El Gosco beech forest, at the 2 sites least affected by human activity, although both are 'naturally protected' by the inaccessibility of the terrain in the ravines where the forest patches are located (Fig. 2).

\section{Fragmentation and connectedness}

The beech forests with the largest number of patches (NumP) are Medio Monte (8), El Gosco (7), and

forest grows between 1800 and $1944 \mathrm{~m}$ asl (Rodríguez-Ramírez \& Moreno 2010), in shallow ravines $\left(<40^{\circ}\right)$, where the temperature ranges from 9 to $16^{\circ} \mathrm{C}$. It is made up of 5 patches located close to each other, but separated by other vegetation types (Pinus patula, Liquidambar styraciflua, and Quercus spp. forests).

(5) Tutotepec (La Cantera) site, San Bartolo Tutotepec municipality (Tables 1 \& 2). Like La Mojonera, El Reparo, and Medio Monte, this is one of the best preserved Mexican beech forests. It has an area of 13.99 ha and is located between 1909 and $1943 \mathrm{~m}$ asl. It has an orobiome similar to Medio Monte, with temperatures between 9 and $15^{\circ} \mathrm{C}$ and high humidity; micro-environmental conditions are characteristic of a mature beech forest (Peters 1992, Fang \& Lechowicz 2006). Access to this site is difficult because of the steep ravines $\left(>42^{\circ}\right)$.

\section{Proposed core areas}

In order to counter the effects on Mexican beech forests of disturbance caused by human activities (changes in land use, climate change, and logging), it is proposed that the connected areas be extended
Tutotepec (7), while the El Reparo beech forest is 1 single continuous patch (Table 2). Analysis of the fragmentation, spatial heterogeneity, configuration, and structure of these Mexican beech forests showed that the largest MPS in these forests in Hidalgo is at the El Reparo site (since this forest is a single patch), and the second largest is at the La Mojonera site, with a MPS of 10.78 ha. The smallest MPS (0.65 ha) is at the El Gosco site, where the beech forest is the smallest in the state and also the most affected by human activity.

The analysis of patch shape complexity (ED) showed that the spatial heterogeneity of the landscape mosaic was highest at the El Gosco site and second highest at the Tutotepec site (Table 2). It is likely that higher patch border complexity is related to illegal logging (at El Gosco) or to the type of spatial arrangement (at Tutotepec).

Consistent with the results reported in the previous paragraph, the estimated AWMSI for the El Gosco site was low (1.1), which supports the idea that human disturbance causes patch shape simplification. The higher AWMSI values for the beech forests at the other 4 sites are characteristic of irregular landscapes, possibly more natural and/or less affected by human activity (Table 2). 
Configuration is measured by the IJI, which was high $(>80 \%)$ at sites less affected by human activity (El Reparo, Tutotepec, La Mojonera, and Medio Monte), indicating that the patches there are more evenly distributed and have not undergone significant changes. In contrast, the IJI value was low (30.4\%) for the El Gosco beech forest (Table 2).

The Medio Monte beech forest had the highest MNN value (38.53), as it is made up of 8 patches, closer together than the average distance between patches at the other sites. The El Reparo site has a zero MNN value because it is a single continuous forest (Table 2).

\section{DISCUSSION}

\section{Size and current distribution of Mexican beech forests}

It is estimated that only one-fifth of the world's original forests are in a favorable state of conservation, these being what have been termed 'forest frontiers' (Bryant et al. 1997). Moreover, some 10\% of the Earth's tree species are considered to be endangered and will probably become extinct if protective measures are not now put into place (González-Espinosa et al. 2011，2012，Ponce-Reyes et al. 2012). In the particular case of Mexico's montane cloud forests, some $60 \%$ of the tree species in these forests are included in some category of risk according to Mexican legislation (SEMARNAT 2010), and there is scant knowledge of the density, coverage, or distribution of populations of most of these species.

The results of the present study provide information on basic aspects needed for implementation of Mexican beech forest management and conservation programs. Previous studies have concluded that there are only 10 remnants of Fagus grandifolia subsp. mexicana forest in the world, and that 3 of these are disappearing or have already disappeared. It was also estimated that they cover an area of less than 60 ha (Williams-Linera et al. 2000, 2003, Rowden et al. 2004). However, we found that these forests occupy a total area of 144.54 ha, i.e. more than double the earlier estimate.

The discovery in the field of a new beech forest site in Hidalgo (El Gosco; present study), and recent data from 2 further sites, one at Agua Fria, Nuevo León, and another at El Reparo, Hidalgo (Montiel-Oscura 2011), have increased the known area covered by 40.05 ha. Additionally, references to the existence of beech forests in Tutotepec, Hidalgo (Williams-Linera et al. 2003), enabled us to locate, describe, and measure 2 further forests, which together cover 48.24 ha, considerably increasing the known area of beech forest in Mexico.

The beech forests of Mexico were separated from those of eastern North America during the Pleistocene. Since then, they have been isolated from their northern counterparts (currently by $>880 \mathrm{~km}$ ) and have been growing under specific environmental conditions for 100s of 1000s of years (Little 1965, Peters 1992, Fang \& Lechowicz 2006, Premoli et al. 2007, Montiel-Oscura 2011). The evidence shows that, in the past, they underwent contraction rather than expansion (Messier et al. 2011) and, in the present day, rising temperatures and falling moisture availability in the environment caused by global warming (Téllez-Valdés et al. 2006), as well as fragmentation and disappearance of the montane cloud forests where small islands of beech forests grow, are rapidly reducing their coverage and distribution (Price et al. 2011).

Although the area occupied by some of the Mexican beech forests has remained relatively unchanged in recent decades, for example, near the Acatlán Volcano, Veracruz (Williams-Linera et al. 2003), and La Mojonera, in the state of Hidalgo (Alcántara \& LunaVega 2001, Rowden et al. 2004, present study), other forests survive with a very small number of beech trees or have disappeared altogether (Williams-Linera et al. 2003). The taxon Fagus grandifolia subsp. mexicana is currently classified as endangered, due mainly to uncontrolled human activity such as changes in land use, forest fires, and illegal logging (Pérez-Rodríguez 1999, Rowden et al. 2004, TéllezValdés et al. 2006, SEMARNAT 2010).

\section{Fragmentation in the beech forest of Hidalgo state}

The largest Mexican beech forests are in the state of Hidalgo, where their combined area is 106.79 ha ( $73.9 \%$ of the national total). The various forest sites exhibit differing degrees of fragmentation and disturbance; the largest ( $54.5 \mathrm{ha}$ ) and least fragmented in the entire country are those in the municipality of Zacualtipán de Ángeles (La Mojonera and El Reparo), as previously suggested by other authors (Pérez-Rodríguez 1999, Alcántara \& Luna-Vega 2001, Williams-Linera et al. 2003). The data of Williams-Linera et al. (2003), Rowden et al. (2004), and the present study show that the Mexican beech forests in San Bartolo Tutotepec (Tutotepec and 
Medio Monte), which cover approximately 48.24 ha, are the least affected by human activity.

The beech forest at the El Gosco site (4.5 ha) in the municipality of Tenango de Doria shows a high degree of deterioration, due mainly to clandestine logging, and will likely soon disappear if measures, such as protecting the zone, are not immediately taken to preserve it.

There are significant differences between the Mexican beech forests studied in terms of the number, shape, and size of the patches (Table 2). It is likely that the effect of disturbances (logging, fires, and diseases) will have different impacts on the composition, structure, and ecological processes in each of the forests (Gang 1998, Messier et al. 2011). Fragmentation of the forests analyzed here does not necessarily imply a high degree of disturbance. For example, MNN values were high for Medio Monte, which means that the patches are relatively close to each other, which allows genetic flow between them (Gelet et al. 2010). Additionally, the degree of grouping, measured by the value of IJI, indicates that there are connections between patches in all the forests studied.

Knowledge about the coverage, degree of fragmentation, and distribution of the beech forests in Mexico is fundamental for establishing management and conservation programs (Alexandrov \& Dakov 2010, Ghalachyan \& Ghulijanyan 2010). Nevertheless, there is still little information about other equally important aspects of these forests, such as species diversity and spatial and temporal dynamics (Alcántara \& Luna-Vega 2001, Williams-Linera et al. 2003, Godínez-Ibarra et al. 2007, Rodríguez-Ramírez \& Moreno 2010). Such information can only be obtained from longer term studies (Pagiola et al. 2003).

Considering that some patches of these Mexican beech forests will soon disappear (Williams-Linera et al. 2003, Rowden et al. 2004, Premoli et al. 2007; El Gosco site in the present study), it is necessary that management plans and protective measures for the short term be proposed and implemented.

\section{Conservation and management proposals for Mexican beech forests}

A viable short-term option is to utilize information from prior studies on other tree species in the same genus (Yilmaz 2010), or in other genera but with similar characteristics or issues to those of Fagus grandifolia subsp. mexicana (Robinson et al.
2009) that could be used as models for management and conservation of beech forests and of this subspecies. Some relevant examples are F. multinervis, endemic to Ulleung Island, Korea, in which genetic studies have helped to preserve the species through maintenance of high heterozygosity (Tomoshi et al. 2006); F. sylvatica, for which regeneration programs have been implemented in areas suffering deforestation in central Europe (Geßler et al. 2007); and F. japonica (in Japan), F. multinervis (in Korea), and F. engleriana (in China), for which areas have been prioritized for conservation to enable these species to recover naturally (Peters 1992, Ohkubo et al. 1996). It is possible that similar methods can help preserve the largest genetic reserve of $F$. grandifolia subsp. mexicana in Mexico. Molecular level data indicate that genetic variation in this subspecies is positively related to population size (Rowden et al. 2004, Premoli et al. 2007). Since the mortality rate of $F$. grandifolia subsp. mexicana seedlings is very high during the first year (Godínez-Ibarra et al. 2007), the persistence of populations depends largely on the implementation of programs to reduce the impact of human activities.

\section{Land ownership}

These beech forests are part of community assets or ejido properties, which means that they are owned communally by the people living in nearby villages (Hardin 1968, Pazos 1991, Congreso de los Estados Unidos Mexicanos 1992, Gutiérrez-Lacayo et al. 2002). As a result, all and each of the ejido members benefit directly from exploitation of the natural resources from these forests (lumber, seeds, land use), and the forests are being consumed rapidly and without regulation (the tragedy of the commons sensu Hardin 1968).

This negative dynamic can, however, be reversed if people's awareness is raised and they are educated (through workshops and information meetings) about the increased benefits they can obtain from proper management of natural forest resources. Some of the environmental services provided by Mexican beech forests can be used directly (mainly edible fungi, seeds, and wood), while indirect services include carbon capture, watershed protection, animal habitats, and recreation. A piece of good news is that in mid-2012, the communal owners of the largest Mexican beech forest (the La Mojonera Ejido), began taking con- 
crete steps to conserve and manage their forest, with help from Mexican public universities and agencies.

\section{Reforestation of Fagus forests with native species}

Mexico has reforestation programs that are based on detailed analyses determining what tree species are suitable for each particular environment. For example, native tree species (Pinus spp., Quercus spp.) are used for reforestation, ideal for the soil type and characteristics where they will be planted (Barry et al. 2010).

In the specific case of Mexican beech forests, the proposal is to increase connectedness between patches through reforestation (Angelsen \& WertzKanounnikoff 2009, Yilmaz 2010) using the most structurally significant native tree species in these forests; Liquidambar styraciflua, Magnolia schiedeana, Pinus patula, Quercus laurina, and Symploccus limoncillo (Williams-Linera et al. 2003, Rowden et al. 2004). The natural coexistence of these species could facilitate the growth of Fagus grandifolia subsp. mexicana seedlings between patches, minimizing the border effect (Guevara \& Laborde 2008, BezauryCreel \& Gutiérrez 2009) and creating concentrations of seeds.

Four further important recommendations are:

(1) Take into account the opinions and empirical knowledge of the residents living near the areas to be reforested, since they are generally the ones who recognize which native species have the best chance of becoming established (Bennet 1999, Wunder 2006, Barry et al. 2010).

(2) Implement mycorrhizal fungi inoculation techniques in reforestation, to increase tree seedling survival probabilities (Rodríguez-Ramírez 2009, Montoya et al. 2010).

(3) Choose suitable tree species for reforestation, considering the characteristics, stage of succession, and degree of disturbance of each forest or forest patch (Morin et al. 2011). For example, in the patches that require immediate reforestation (e.g. El Gosco, in Tenango de Doria), species that improve soil quality are suggested (Angelsen \& Wertz-Kanounnikoff 2009, Morin et al. 2011).

(4) Implement 'reducing emissions from deforestation and forest degradation' (REDD+) programs at the state level that will help ejido members reduce pressure on the natural resources they obtain from beech forests by enabling them to obtain a good price for their agricultural products. The environment and the populations will benefit in the medium- to long term from the reduction in greenhouse gas emissions (CONAFOR 2010).

\section{Beechnut consumption}

One of the most critical problems for the survival of Fagus grandifolia subsp. mexicana populations is related to the tree's life cycle. Beech trees produce seeds synchronously in certain years, called 'mast years,' and the rate of seedling establishment after germination is low (Ehnis 1981, Álvarez-Aquino \& Williams-Linera 2002, Godínez-Ibarra et al. 2007). In mast years (which occur every 5 to $8 \mathrm{yr}$ ), local residents collect the seeds (beechnuts) to eat and/or sell locally, which could decrease the natural regeneration of trees.

To increase the viability of Fagus seeds and the rate of seedling establishment, it is necessary to gradually regulate the practice of seed harvesting, considering the size, degree of disturbance, and fragmentation of each forest. Ejido members and residents of villages near the beech forests must be helped to understand the importance of regulating and controlling Fagus seed harvesting, which will benefit the sustainable use of forest resources and, in consequence, development in local communities (Blyth et al. 1995, Saunders et al. 1995).

A practice recommended to increase the population viability of Fagus grandifolia subsp. mexicana is to produce seedlings raised from seed in nurseries. Further experimental protocols could be used to increase germination and seedling survival (Arriaga et al. 1994), for example, inoculating seeds or seedlings with native fungi (Rodríguez-Ramírez 2009, Montoya et al. 2010).

During field trips undertaken in February 2012, it was observed that Fagus grandifolia subsp. mexicana trees were flowering synchronously in the 5 beech forests in Hidalgo; the forest floor was abundantly carpeted with beech flowers and pollen. Later, during June and July, the first young fruits were observed, and by mid-September 100s of 1000s of seeds were germinating. It was impossible to walk in the woods without crushing tiny Fagus seedlings at every step.

Although in this mast year the majority of seedlings did not survive (Godínez-Ibarra et al. 2007), it is encouraging to know that the Mojonera forest ejido residents are collecting seeds for the tree nursery that they began to build in late September 2012 (pers. comm. from ejido members) to ensure the sur- 
vival of more seedlings, promote forest regeneration, and increase the connectivity of the forest fragments by planting trees at suitable sites.

Only by means of a long-term demographic study can the consequences of harvesting the beechnuts be unraveled (Álvarez-Aquino \& Williams-Linera 2002, Godínez-Ibarra et al. 2007). Many demographic data on long-lived plants show that even harvesting $>90 \%$ of the seeds of a population does not lower the intrinsic rate of population growth (Cleavitt et al. 2008, Barna et al. 2009).

\section{Incorporation into the national system of Natural Protected Areas}

The results of the present study show that the Mexican beech forests are at imminent risk of extinction, as they have a total area of $<160$ ha and are decreasing in area both in Hidalgo and nationally. For this reason, we urge that a conservation and management program be implemented for Mexican beech forests, which would be integrated into the national system of Natural Protected Areas, supported by Mexican law. A fact that may help is that this plant association includes a variety of animal, fungus, and plant species that are included in some risk category either under the NOM-059 standard (SEMARNAT 2010) or in the Red List of Mexican cloud forest trees (González-Espinosa et al. 2011). The plants include Fagus grandifolia subsp. mexicana and Magnolia schiedeana, listed as being in danger of extinction ${ }_{i}$ species of tree ferns (Cyathea fulva and Dicksonia sellowiiana); the less conspicuous ferns Marattia weinmanniifolia and Psilotum complanatum; and several species of orchids.

Acknowledgements. The first author is grateful to Guadalupe Pérez-Paredes for her field work support at all the Mexican beech forest sites. This study was supported by the Consejo Nacional de Ciencia y Tecnología (CONACYT), through (1) a graduate grant awarded to the first author and (2) funding for the Ciencia Básica 2011 Project 169141 'Estructura, diversidad de especies vegetales y distribución actual de los bosques de haya (Fagus grandifolia subsp. mexicana) en el estado de Hidalgo, México' (Structure, plant species diversity and current distribution of beech (Fagus grandifolia subsp. mexicana) forests in the state of Hidalgo, Mexico).

\section{LITERATURE CITED}

Alcántara AO, Luna-Vega I (2001) Análisis florístico de dos áreas con bosque mesófilo de montaña en el estado de Hidalgo, México: Eloxochitlán y Tlahuelompa. Acta Bot Mex 54:51-87
Alexandrov HA, Dakov A (2010). Current state of European beech (Fagus sylvatica L.) and oriental beech (Fagus orientalis LIPSKY) gene-pool in Bulgaria. In: Frýdl J, Novotný P, Fennessy J, Wühlisch G (eds) Cost Action E52, genetic resources of beech in Europe. Johann Heinrich von Thünen-Institut, Landbauforschung vTI Agriculture and Forestry Research, Brunswick, p 61-69

Álvarez-Aquino C, Williams-Linera G (2002) Seedling bank dynamics of Fagus grandifolia var. mexicana before and after a mast year in a Mexican cloud forest. J Veg Sci 13: 179-184

Álvarez-Aquino C, Williams-Linera G, Newton AC (2004) Experimental native tree seedling establishment for the restoration of a Mexican cloud forest. Restor Ecol 12: 412-418

Angelsen A, Wertz-Kanounnikoff S (2009) What are the key design issues for REDD and the criteria for assessing options? In: Angelsen A (ed) Moving ahead with REDD: issues, options and implications. Center for International Forestry Research, Bogor, p 11-22

Arriaga VM, Cervantes VG, Vargas-Mena A (1994) Manual de reforestación con especies nativas. Secretaría de Desarrollo Social, Instituto Nacional de Ecología and Universidad Nacional Autónoma de México, Mexico, Distrito Federal, p 39-43

Barna M, Schieber B, Cicák A (2009) Effects of post-cutting changes in site conditions on the morphology and phenology of naturally regenerated beech seedlings (Fagus sylvatica L.). Pol J Ecol 57:461-472

Barry D, Bray D, Madrid S, Merino L, Zúñiga I (2010) El manejo forestal sostenible como estrategia de combate al cambio climático: las comunidades nos muestran el camino. Consejo Civil Mexicano para la Silvicultura Sostenible (CCMSS), Rights + Resources, Monterrey, Nuevo León

Bennet AF (1999) Linkages in the landscape: the role of corridors and connectivity in wildlife conservation. IUCN, Gland,

Bezaury-Creel J, Gutiérrez CD (2009) Áreas naturales protegidas y desarrollo social en México. In: Capital natural de Mexico, Vol II: estado de conservación y tendencias de cambio. Comision Nacional para el Conocimiento y Uso de la Biodiversidad, México, Distrito Federal, p 385-431

Blyth JD, Burbidge AA, Brown AP (1995) Achieving cooperation between government agencies and the community for nature conservation, with examples from the recovery of threatened species and ecological communities. In: Saunders DA, Craig JL, Mattiske EM (eds) Nature conservation 4 . The role of networks. Surrey Beatty \& Sons, Chipping Norton, p 343-367

Bryant D, Nielsen D, Tangley L (1997) The last frontier forests: ecosystems and economies on the edge. World Resources Institute, World Conservation Monitoring Centre and World Wildlife Fund, Washington, DC, p 6-11. http://pdf.wri.org/lastfrontierforests.pdf

CITES (Convention on International Trade in Endangered Species of Wild Fauna and Flora) (2010) Appendices I, II and III. Available at www.cites.org (accessed 21 May 2012)

Cleavitt NL, Fairbairn M, Fahey TJ (2008) Growth and survivorship of American beech (Fagus grandifolia Ehrh.) seedlings in a northern hardwood forest following a mast event. J Torrey Bot Soc 135:328-345 
CONAFOR (Comisión Nacional Forestal) (2010) Visión de México sobre REDD ${ }^{+}$hacia una estrategia nacional 1st edn. Gobierno Federal, Secretaria del Medio Ambiente y Recursos Naturales, Zapopan, Jalisco

Congreso de los Estados Unidos Mexicanos C (1992) Ley agraria. Diario Oficial de la Federación, Febrero 26, 1992, México, Distrito Federal

Denk T (2003) Phylogeny of Fagus L. (Fagaceae) based on morphological data. Plant Syst Evol 240:55-81

Ehnis DE (1981) Fagus mexicana Martínez: su ecología e importancia. BSc thesis, Facultad de Ciencias, Universidad Nacional Autónoma de México, México, Distrito Federal

Elkie P, Rempel R, Carr A (1999) Patch analyst user's manual: a tool for quantifying landscape structure. Technical Manual TM002, Ontario Ministry of Natural Resources Boreal Science, Northwest Science \& Technology, Thunder Bay

Ern H (1976) Descripción de la vegetación montañosa de los estados mexicanos de Puebla y Tlaxcala. Willdenowia Beiheft 10, Botanischer Garten und Botanisches Museum, Berlin

ESRI (Environmental Systems Research Institute) (2002) ArcView GIS v.3.3. ESRI, New York, NY

Fang J, Lechowicz MJ (2006) Climatic limits for the present distribution of beech (Fagus L.) species in the world. J Biogeogr 33:1804-1819

FAO-UNESCO (1988) Soil map of the world. Revised Legend. World Soil Resources Report 60. FAO-UNESCO Rome

Fonseca F, Figueiredo T, Martins A (2011) Survival and early growth of mixed forest stands installed in a Mediterranean region: effects of site preparation intensity. For Ecol Manag 262:1905-1912

Forman RTT (1995) Land mosaic. The ecology of landscapes and regions. Cambridge University Press, Cambridge

Forman RTT, Godron M (1981) Patches and structural components for a landscape ecology. Bioscience 31:733-740

Fox WB, Sharp AJ (1954) La distribución de Fagus en México. Bol Soc Bot Mex 17:31-33

- Frankham R, Ballou JD, Dudash MR, Eldridge MDB and others (2012) Implications of different species concepts for conserving biodiversity. Biol Conserv 153:25-31

Gang W (1998) Distribution, regeneration and succession of Fagus. J For Res 9:290-291

García E (1988). Modificaciones al sistema de clasificación climática de Köppen, quinta edn. Universidad Nacional Autónoma de México, Instituto de Geografía, México, Distrito Federal

Gelet M, Suryabhagavan KV, Balakrishnan M (2010) Landuse and landscape pattern changes in Holeta-Berga watershed, Ethiopia. Int J Ecol Environ Sci 36:117-132

Geßler A, Keitel C, Kreuzwieser J (2007) Potential risk for European beech (Fagus sylvatica L.) in a changing climate. Trees (Berl) 21:1-11

Ghalachyan H, Ghulijanyan A (2010) Current state of oriental beech (Fagus orientalis Lipsky) in Armenia. In: Frýdl J, Novotný P, Fennessy J, Wühlisch G (eds) Cost Action E52, genetic resources of beech in Europe. Johann Heinrich von Thünen-Institut, Landbauforschung vTI Agriculture and Forestry Research, Brunswick, p 26-37

Girvetz EH, Greco SE (2007) How to define a patch: a spatial model for hierarchically delineating organism-specific habitat patches. Landscape Ecol 22:1131-1142

Godínez-Ibarra O, Ángeles-Pérez G, López-Mata L, García-
Moya E, Valdez-Hernández JV, Santos-Posadas H, Trinidad-Santos A (2007) Lluvia de semillas y emergencia de plántulas de Fagus grandifolia subsp. mexicana en La Mojonera, Hidalgo, México. Revista Mexicana de Biodiversidad 78:117-128

González-Espinosa M, Meave JA, Lorea-Hernández FG, Ibarra-Manríquez G, Newton AC (2011) The Red List of Mexican cloud forest trees. Fauna \& Flora International, Cambridge

González-Espinosa M, Meave JA, Ramírez-Marcial N, Toledo-Aceves T, Lorea-Hernández FG, Ibarra-Manríquez G (2012) Los bosques de niebla de México: conservación y restauración de su componente arbóreo. Ecosistemas 21:36-52

Guevara S, Laborde J (2008) The landscape approach: designing new reserves for protection of biological and cultural diversity in Latin America. Environ Ethics 30: 251-262

Gutiérrez-Lacayo M, Bacmeister A, Ortiz-Martínez de Korez G, Ortiz-Reyes G, Montesinos C (2002) Herramientas legales para la conservación de tierras privadas y sociales en México. Pronatura, México, Distrito Federal

Hardin G (1968) The tragedy of the commons. Science 162: 1243-1248

Horikawa Y (1972) Atlas of the Japanese flora: an introduction to plant sociology of East Asia. Gakken, Tokyo

> Huntley B, Bartlein PJ, Prentice IC (1989) Climatic control of the distribution and abundance of beech (Fagus L.) in Europe and North America. J Biogeogr 16:551-560

Little EL (1965) Mexican beech, a variety of Fagus grandifolia. Castanea 30:167-170

Martínez M (1940) Una nueva especie forestal (Fagus mexicana sp. nova). Anales del Instituto de Biología. Universidad Nacional Autónoma de México 11:85-89

Maxwell EL (1982) The relative importance of the spectral, spatial and temporal domains. In: Brann TB, House LO, Lund HG (eds) In-place resource inventories: principles and practices. Proceedings of a national workshop. Society of American Foresters, Bethesda, MD, Publ 82-02, p 232-241

Messier C, Bélanger N, Brisson J, Lechowicz MJ, Gravel D (2011) Comment on 'Present-day expansion of American beech in northeastern hardwood forests: Does soil base status matter?'. Can J For Res 41:649-653

> Milad M, Schaich H, Bürgi M, Konold W (2011) Climate change and nature conservation in Central European forests: a review of consequences, concepts and challenges. For Ecol Manag 261:829-843

Miranda F, Sharp AJ (1950) Characteristics of the vegetation in certain temperate regions of eastern Mexico. Ecology 31:313-333

Montiel-Oscura D (2011) Estructura poblacional y genética de Fagus grandifolia subsp. mexicana. MSc thesis, Colegio de Postgraduados, Campus Montecillo, Texcoco

> Montoya L, Haug I, Bandala VM (2010) Two Lactarius species associated with a relict Fagus grandifolia var. mexicana population in a Mexican montane cloud forest. Mycologia 102:153-162

Morin X, Fahse L, Scherer-Lorenzen M, Bugmann H (2011) Tree species richness promotes productivity in temperate forests through strong complementarity between species. Ecol Lett 14:1211-1219

Ohkubo T, Tanimoto T, Peters R (1996) Response of Japanese beech (Fagus japonica Maxim.) sprouts to canopy gaps. Vegetatio 124:1-8 
Pagiola S, Bishop J, Landell-Mills N (2003) La venta de servicios ambientales forestales. Secretaría de Medio Ambiente y Recursos Naturales, Instituto Nacional de Ecología, Comisión Nacional Forestal, México, Distrito Federal

Pazos L (1991) La disputa por el ejido. Editorial Diana, México, Distrito Federal

Pérez-Rodríguez PM (1999) Las hayas de México, monografía de Fagus grandifolia spp. mexicana. Universidad Autónoma Chapingo, Chapingo

Peters R (1992) Ecology of beech forests in the northern Hemisphere. PhD thesis, Wageningen Agricultural University, Wageningen

Peters R (1995) Architecture and development of Mexican beech forest. Vegetation science in forestry. In: Box EO, Peet RK, Masuzawa T, Yamada I, Fujiwara K, Maycock $\mathrm{PF}$ (eds) Vegetation science in forestry. Kluwer Academic Publishers, Dordrecht, p 325-343

Ponce-Reyes R, Reynoso-Rosales VH, Watson JEM, VanDerWal J, Fuller RA, Pressey RL, Possingham HP (2012) Vulnerability of cloud forest reserves in Mexico to climate change. Nature Clim Change 2:448-452

Premoli AC, Del Castillo RF, Newton AC, Bekessy S and others (2007) Patterns of genetic variation in tree species and their implications for conservation. In: Newton AC (ed) Biodiversity loss and conservation in fragmented forest landscapes: the forests of montane Mexico and temperate South America. CAB International, Wallingford, p 120-157

Price MF, Gratzer G, Duguma LA, Kohler T, Maselli D, Rosalaura R (2011) Mountain forests in a changing worldRealizing values, addressing challenges. FAO/MPS and SDC, Rome

Riitters KH, O'Neill RV, Hunsaker CT, Wickham JD and others (1995) A factor analysis of landscape pattern and structure metrics. Landscape Ecol 10:23-29

Robinson D, Perpetua G, Stewart C, Rayden T (2009) FSC step-by-step guide: good practice guide to meeting FSC certification requirements for biodiversity and high conservation value forests in small and low intensity managed forests. Forest Stewardship Council A.C., FSC International Center, Bonn

Rodríguez-Ramírez ECh (2009) Diversidad de la familia Boletaceae en dos bosques de Fagus grandifolia var. mexicana en el estado de Hidalgo, México. MSc thesis, Universidad Autónoma del Estado de Hidalgo, Hidalgo

Rodríguez-Ramírez ECh, Moreno CE (2010) Bolete diversity in two relict forests of the Mexican beech (Fagus grandifolia var. mexicana; Fagaceae). Am J Bot 97:893-898

Rose L, Leuschner C, Köckemann B, Buschmann H (2009) Are marginal beech (Fagus sylvatica L.) provenances a source for drought tolerant ecotypes? Eur J For Res 128: 335-343

Rowden A, Robertson A, Allnutt T, Heredia S, Williams-

Editorial responsibility: Hans Juergen Boehmer, Bonn, Germany
Linera G, Newton AC (2004) Conservation genetics of Mexican beech, Fagus grandifolia var. mexicana. Conserv Genet 5:475-484

Saunders DA, Craig JL, Mattiske EM (1995) Nature Conservation 4: the role of networks. Surrey Beatty \& Sons, Chipping Norton

SEMARNAT (Secretaría del Medio Ambiente y Recursos Naturales) (2010) Norma Oficial Mexicana NOM-059SEMARNAT-2010, Protección ambiental-Especies nativas de México de flora y fauna silvestres-Categorías de riesgo y especificaciones para su inclusión, exclusión o cambio-Lista de especies en riesgo. Diario Oficial de la Federación. Segunda Sección, México, Distrito Federal. www.profepa.gob.mx/innovaportal/file/ 435/1/NOM_059_SEMARNAT_2010.pdf

Téllez-Valdés O, Dávila-Aranda P, Lira-Saade R (2006) The effects of climate change on the long term conservation of Fagus grandifolia var. mexicana, an important species of the cloud forest in eastern Mexico. Biodivers Conserv 15:1095-1107

Tinoco-Rueda JA, Toledo-Medrano ML, Carrillo-Negrete IJ, Monterroso-Rivas I (2009) Clima y variabilidad climática en los municipios de Hidalgo con presencia de bosque mesófilo de montaña. In: Monterroso-Rivas AJ (ed) El Bosque Mesófilo en el Estado de Hidalgo. Perspectiva ecológica frente al cambio climático. Universidad Autónoma Chapingo, Texcoco, p 71-98

Tomoshi O, Keiko K, Hideki T, Shoichi K (2006) Genetic variation in Fagus multinervis Nakai (Fagaceae), a beech species endemic to Ullung Island, South Korea. Plant Species Biol 2:135-145

Valencia AS, Flores-Franco G (2006) Catálogo de autoridades taxonómicas de las fagáceas (Fagaceae: Magnoliopsida) de México. Base de datos SNIB-CONABIO, Proyecto CS008, Universidad Nacional Autónoma de México, México, Distrito Federal

Williams-Linera G, Devall MS, Álvarez-Aquino C (2000) A relict population of Fagus grandifolia var. mexicana at the Acatlán Volcano, Mexico: structure, litterfall, phenology and dendroecology. J Biogeogr 27:1297-1309

Williams-Linera G, Rowden A, Newton AC (2003) Distribution and stand characteristics of relict populations of Mexican beech (Fagus grandifolia var. mexicana). Biol Conserv 109:27-36

> Wilson HB, Liana NJ, Moore AL, Possingham HP (2011) When should we save the most endangered species? Ecol Lett 14:886-890

Wunder S (2006) Payments for environmental services: some nuts and bolts. Occasional Paper No. 42, Center for International Forestry Research, Jakarta

Yilmaz M (2010) Is there a future for the isolated oriental beech. (Fagus orientalis Lipsky) forests in southern Turkey? Acta Silvat Lignaria Hung 6:111-114

Submitted: May 31, 2012; Accepted: January 18, 2013

Proofs received from author(s): May 7, 2013 